IZA DP No. 7658

Labor Market Transparency

Eskil Wadensjö

September 2013

Forschungsinstitut zur Zukunft der Arbeit Institute for the Study of Labor 


\title{
Labor Market Transparency
}

\author{
Eskil Wadensjö \\ SOFI, Stockholm University \\ and IZA
}

\section{Discussion Paper No. 7658 \\ September 2013}

\author{
IZA \\ P.O. Box 7240 \\ 53072 Bonn \\ Germany \\ Phone: +49-228-3894-0 \\ Fax: +49-228-3894-180 \\ E-mail: iza@iza.org
}

\begin{abstract}
Any opinions expressed here are those of the author(s) and not those of IZA. Research published in this series may include views on policy, but the institute itself takes no institutional policy positions. The IZA research network is committed to the IZA Guiding Principles of Research Integrity.

The Institute for the Study of Labor (IZA) in Bonn is a local and virtual international research center and a place of communication between science, politics and business. IZA is an independent nonprofit organization supported by Deutsche Post Foundation. The center is associated with the University of Bonn and offers a stimulating research environment through its international network, workshops and conferences, data service, project support, research visits and doctoral program. IZA engages in (i) original and internationally competitive research in all fields of labor economics, (ii) development of policy concepts, and (iii) dissemination of research results and concepts to the interested public.
\end{abstract}

IZA Discussion Papers often represent preliminary work and are circulated to encourage discussion. Citation of such a paper should account for its provisional character. A revised version may be available directly from the author. 
IZA Discussion Paper No. 7658

September 2013

\section{ABSTRACT}

\section{Labor Market Transparency*}

The labor market differs from other markets in many respects. Most important is that those who supply labor also have to deliver it in person. It means firstly that the work environment and organization of work are important for those who deliver labor, since they are in the work place. Secondly, the result of a person's work varies with the price of labor (remuneration) and how the work is organized. Thirdly, the definition of work or a job for an employed person is not fixed but dependent on the person. The paper firstly deals with economic models of labor supply, labor demand, labor remuneration and labor market information. The subsequent sections discuss complications regarding labor market transparency in the context of international migration and public policy and policy implications regarding labor market transparency. A final section concludes.

JEL Classification: F22, J22, J23, J30

Keywords: labor market information, labor demand, labor supply, wages, international migration, transparency in the labor market

Corresponding author:

Eskil Wadensjö

Swedish Institute for Social Research (SOFI)

Stockholm University

10691 Stockholm

Sweden

E-mail: eskil.wadensjo@sofi.su.se

\footnotetext{
* Forthcoming in: Handbook of Political, Institutional, and Corporate Transparency, Jens Forssbaeck and Lars Oxelheim (Eds.), Oxford University Press. I would like to thank Christer Gerdes, Phillip Martin, Anders Stenberg and Yuyu Wang for valuable comments on earlier versions.
} 
The labor market differs from other markets in many respects. Most important is that those who supply labor also have to deliver it in person, so that the work environment and organization of work are important for those who deliver labor, as they have to be at the work place. ${ }^{1}$ Secondly, the result of a person's work varies with the price of labor (remuneration) and how the work is organized. Thirdly, the definition of work or a job for an employed person is not fixed but dependent on the person.

Information is crucial for the functioning of the labor market. ${ }^{2}$ There is much information on the labor market from official authorities, unions, employer associations, newspapers etc. but transparency is lacking in several respects. In this chapter I discuss different aspects of information and transparency in the labor market. The chapter is organized in the following way: the next four sections deal with labor supply, labor demand, labor remuneration and labor market information. The following sections discuss complications regarding transparency in the context of international migration, the conditions for migrant workers, and public policy. A final section concludes.

\section{Sources of Lack of Transparency in the Labor Market}

Transparency problems are different for the supply side and the demand side of the labor market. Workers and employers look for different types of the information. The information is asymmetric. Of interest to both parties is the remuneration.

\subsection{Labor Supply}

In the labor market there is a large variation in both workers and jobs, creating a matching problem. And as information is not easily available there are important differences compared to a perfect labor market with standard workers and standard jobs and complete and free directly available information for both sides. The workers looking for a job have in many cases several different alternatives and, at the start of the search process, often have limited information on the alternatives available. A person who is unemployed and looking for a job has a minimum or reservation wage or package, meaning she will not accept a job offering less, instead searching for a job that satisfies this reservation package, an example of search

\footnotetext{
${ }^{1}$ Exceptions are those who have the workplace at home.

${ }^{2}$ See Stigler (1962) for an early contribution to the theoretical development of information in the labor market.
} 
unemployment. ${ }^{3}$ The reservation wage varies depending on education and earlier work experience. It can vary over time, rising or falling as the worker learns more about the labor market. The search period and the reservation wage vary over the business cycle and by alternative income compensation available as for example compensation from unemployment insurance. Higher compensation when unemployed may increase the reservation wage and lengthen the unemployment spell.

Many employed workers also seek new jobs. They want to make a career by changing to another employer or want a change for other reasons. Most people have more than one job over their working careers. It is typical for young people entering the labor market to change jobs frequently before staying at a job for an extended period. It can be seen as a form of job shopping - learning by testing different jobs. ${ }^{4}$ The labor market and jobs are not transparent, so job shopping could be an efficient method to learn the characteristics of the job by being employed.

A person's productivity at a job is not fixed. The person may acquire new abilities on the job via formal training on the job and learning by doing. ${ }^{5}$ Important for getting a job and for getting a specific type of job is education - investment in human capital - mainly before entering the labor market. Education leads to ability to do different jobs but it may also signal the abilities of the person. ${ }^{6}$ A person who has taken part in a difficult educational program with good grades demonstrates high ability to the prospective employer. More experience in the labor market also means on average higher productivity, but the addition of knowledge for each additional year at work may decline with the number of years in the labor market. In a simple form of earnings equation, the Mincer equation, the earnings (the wage rate) are explained by the number of years in school and the number of years of work experience (first and second grade terms). Adding other explanatory variables, including seniority, gender, ethnicity and civil status, make it possible to estimate the existence and size of discrimination and generally to take account of other variables that influence wages. The problem with this method for estimating discrimination is that it does not take account of non-observable variables which may influence wages.

\footnotetext{
${ }^{3}$ See Phelps (ed.) (1970) and Phelps (1972a) for early references on search unemployment and Mortensen (1986) and Mortensen and Pissarides (1999) for surveys.

${ }^{4}$ See Jovanovic (1979) for an analysis of job shopping.

${ }^{5}$ See Arrow (1962) for learning by doing and Becker (1964) for firm-specific education.

${ }^{6}$ See Spence (1974) for the theory that sees education as a signal regarding ability. This form of influence of education on wages is also called sorting. Those who are not able to be accepted on a certain level or are not fulfilling the requirements of education at that level are sorted away (and get a lower wage as they are showing a lower ability).
} 
The matching of unemployed and vacancies can be illustrated by the Beveridge curve - the more vacancies the fewer unemployed and vice versa. ${ }^{7}$ The further out the curve is situated the more complicated is the matching. One of the factors that contribute to inefficient matching is lack of transparency - it takes time to find a suitable vacant job even if it is there. The Beveridge curve differs between countries and in a country over time. The Beveridge curve has in some countries in recent years moved outwards (becoming less favorable). One factor may be that the vacancies and the unemployed do not match regarding education and educational requirements or other characteristics of jobs and workers, but declining transparency in an increasingly diverse labor market may also be a factor. That the employees do not have transparency may lead to that the employer get monopsony power. ${ }^{8}$

The wiring of the labor market - that it is easy to find information regarding vacancies on internet - may in the long run lead to faster matches. ${ }^{9}$ The person looking for a job may also find information on the employer on the internet, just as the employer may find information on job applicants. This may lead to better matches but also to some problems regarding privacy. Another development in recent years is the growth of temporary employment agencies. They employ people and send them to other employers for shorter or longer periods. They are in a way specializing in recruitment of personnel but also in combining different part-time or short-term jobs to full time employment. ${ }^{10}$

\subsection{Labor Demand}

Employers have a demand for specific types of labor; they want productive workers. It is not easy to ascertain the productivity of a person who applies for a job, since ability is not transparent and easy to evaluate by looking at job applications and CVs. The selection of workers is often done in several steps. ${ }^{11}$ First a position is announced, some of the applicants are selected for several rounds of interviews and tested, and finally a person is hired for the vacant position. In many cases the newly hired employee first gets a contract for a trial period with a relatively low wage. Thereafter a decision is taken regarding tenure and a higher wage. The trial period can also serve as a form of self-selection of workers. Those who know that

\footnotetext{
${ }^{7}$ For the first article on the Beveridge curve, see Dow and Dicks-Mireaux (1958).

${ }^{8}$ Se Manning (2003, 2011) and Ashenfelter et al. (2010).

${ }^{9}$ See Autor (2001) for a discussion.

${ }^{10}$ See for example Houseman et al. (2003).

11 This and other issues regarding recruitment and advancement inside a firm are covered by "personnel economics”. See for example Lazear (1999), Lazear and Shaw (2007) and Oyer and Schaefer (2011) for surveys of this part of economic theory.
} 
they will not be able to pass the test in the trial period abstain from applying as they know that they will only be employed for the trial period with a low wage.

Only in a minority of cases is piece-rate payment the main wage form selected by the employer. In most cases a time-based wage is paid as the main form even if it is not possible to know the productivity of the worker. It does not mean that there is not a demand for measurement of productivity or that the pay is not related to productivity. On the contrary, employers are eager to measure individual productivity, but not on an hourly or daily basis. In many cases, a worker's productivity is measured relative to other workers in a way which may be labeled a tournament. The winners of the tournament are promoted or get higher pay. In most cases there are several levels in the hierarchy of the firm and several "prizes" in the tournament.

It may be difficult to motivate workers who are not promoted to be productive and not shirk. One way to motivate them to do a good job is to defer some of their compensation for example by paying more senior people more (even if they do not become more productive over time) or by a company pension or another reward for those who stay until retirement. Such a system motivates workers to stay and do a good job so that they do not miss the deferred payment. Another way to induce workers to be efficient and not shirk is to pay workers a wage higher than the market wage, to pay “efficiency wages”. See Shapiro and Stiglitz (1974) for an early contribution to this part of wage and unemployment theory. An efficiency wage makes it more expensive for a worker to lose the job due to shirking. A higher wage than the market wage may also be seen as a gift to the worker and the worker may respond by being more productive. ${ }^{12}$

A further complication in the demand for labor is that the jobs in many cases are not fixed but adjusted to those employed and their abilities. Different work tasks are combined to jobs depending on the abilities of a worker. ${ }^{13}$ It is difficult in advance to know what the combination will look like.

\subsection{Remuneration}

The wage an employee receives may not be a specific amount of money. There may be a basic wage (for hours or piece-rate), a bonus, a wage rate for overtime hours, and a wage rate

\footnotetext{
${ }^{12}$ See Akerlof (1982).

${ }^{13}$ See for example Autor (2013) for a theory of labor demand based on work tasks.
} 
for work on evenings and weekends etc. It is therefore not easy to compare the wages of different job offers.

The wage is not the only part, even if often the most important part, of the remuneration. There are several other forms of compensation and different forms of fringe benefits. Often very important are different forms of social and occupational insurance. They can be the same system for everyone (social insurance related to labor income), determined industry-wide by agreements between a union and an employer association, and also be specific to the employer or the individual employment contract. ${ }^{14}$ There may be other fringe benefits related to the job, such as a company car, free or subsidized housing, lunch or other meals at the work place etc. ${ }^{15}$ It is not only the wage and related remuneration when being hired that is important, but also the expected career afterwards at the employer.

Very important is also the work environment at the work place. The risk of occupational injuries is one aspect, but the behavior of work mates and how the work is organized and led are factors difficult or impossible to learn until a worker is on the job.

Adam Smith (1776, 1981, pp. 116-135) outlined different aspects of importance for the wage setting and wage differences. This analysis is often called the theory of comparable worth. He listed five factors leading to wage differences:

1. The hardship, the cleanliness or dirtiness, the honorableness or dishonorableness of the employment.

2. The ease and cheapness, or the difficulty and expense of learning the business.

3. The constancy or inconstancy of employment.

4. The smaller or greater trust reposed in the workmen.

5. The probability or improbability of success.

Adam Smith also mentioned other factors leading to wage differences, for example that higher wages were paid in expanding industries (Smith 1776, 1981, p. 131). The firms in those industries have to pay more to be able to recruit workers. According to Adam Smith (pp. 135-159) the wage structure was also influenced by public policy such that the supply of

\footnotetext{
${ }^{14}$ See Ebbinghaus (2011) for studies of the complicated structure of occupational pensions in a number of countries. Many of those who have a right to supplementary compensation may miss the compensation due to lack of information. See Sjögren Lindquist and Wadensjö (2006) for Sweden. See La lettre de l'Observatoire des Retraites (2010) for the importance to inform about the pension systems.

${ }^{15}$ See Granqvist (1998) for studies of fringe benefits in Finland with a survey of studies covering other countries, and Granqvist (1997) for a study on Sweden.
} 
workers to some occupations was subsidized, the supply in other occupations was restricted and mobility between parts of the labor market was restricted.

\subsection{Information regarding the labor market}

It is obvious that the labor market is sometimes not very transparent for workers and employers. The public authorities have a good overview of the rules regulating the labor market, but the statistics and the statistical databases are only partial. The wage statistics may be good, but the information on non-wage remuneration is often lacking.

Governments collect and disseminate information on the labor markets mainly through their Central Statistical Offices. The information is of several different types: Surveys (as the Labor Force Surveys), statistics based on administrative registers, and censuses. The information covers different parts and aspects of the labor market and the information is sometimes dated when published.

The labor force surveys are made with short intervals and rapidly published, but they are based on small samples of the population, limiting their use in particular labor markets. The register-based statistics are only published or made available in other ways with a time lag (years in some occasions) and there may be problems in getting access to the information due to data security restrictions. The quality of the information in the registers also varies between countries.

A census covers all residents of a country at a specific point of time, but censuses are only made at large time intervals (usually every tenth year), are in most cases published a long time after the data collection, and are not carried out in all countries (for example not in Sweden since 1990).

The Labor Market Administrations are other sources of information with information on for example job vacancies and those searching for a job, both unemployed and employed looking for a new job. The coverage varies a great deal among countries.

The social partners, the employer associations and the unions, collect and produce information for their members and also to some extent for the general public. The extent and quality varies greatly among countries. The share of employers and workers who are members of organizations differs between countries. 
For individuals other sources may be more important such as media and networks. ${ }^{16}$ The media gives the general picture and the networks information on specific workplaces. Relatives and friends inform on the conditions at the work places. Those who mainly have relatives and friends who do not have jobs have weaker networks regarding job information. ${ }^{17}$

The information available to the employer differs regarding different groups of job applicants. It is often difficult to evaluate the capacity of people with different forms of functional impairments. They may therefore be discriminated due to the lack of information. The labor market administration's role as information provider is here even more important than it is for most other job applicants. The same may be said for those entering a labor market as young people and newly arrived refugees. The labor market is characterized by asymmetric information - the actors on the two sides of the labor market have different information.

\section{An international labor market}

As shown above, the transparency of the labor market is limited even for those who are born in a country and have lived there all their lives. The transparency is of course often even more limited for those who migrate over the border to another country and those who have lived in the country of destination for only part of their working life. The transparency is not only limited regarding prospective jobs, but also regarding other conditions in the destination country. It may also be more difficult for the employer to evaluate the credentials of foreignborn workers. $^{18}$

\subsection{Migration}

People move for various reasons to another country - work, study, family reasons and as refugees are the most common ones. I will here primarily discuss those who migrate for work. Many of those who migrate for work already have a job at arrival. They have applied for a job or been recruited by an employer in the country of destination. Others have secured a job with the help of relatives or friends - a network effect. It is also possible for those looking for a job in another European Union country to do so by going to that country for up to three months without a special permit.

\footnotetext{
${ }^{16}$ On networks in general on the labour market see for example Granovetter $(1973,1983)$ and Rees (1966).

${ }^{17}$ See Montgomery (1991) for the United States and Olli Segendorf (2005) for Sweden.

${ }^{18}$ See for example Katz and Stark (1987) on asymmetric information in international migration.
} 
In most cases, those arriving from another country for work have information only on a limited part of the labor market, in some cases only about the job to which they have been recruited. The labor market is not transparent on arrival. Several studies show that there is gradual wage assimilation - in some cases leading to higher wages than the wages of natives with the same characteristics due to a positive selection of those who migrate. ${ }^{19}$ Getting a higher wage by higher seniority and by learning the language of the destination country are explanations for the wage assimilation, but also better knowledge about the labor market in the country of destination. The labor market gradually becomes more transparent for those immigrants who integrate.

Information is important not only on the gross wage but also on taxes (the net wage) and what the taxes are used for, such as health care, education and child care. Important is also how the migrants are treated in the legal framework and if there is discrimination by employers and native workers. The possibilities to be joined by family members and the qualifications for becoming a citizen in the new country may also be important.

There are other groups of migrants. Those coming to a country as students and who want to stay in the country after completed studies may get information regarding the labor market when studying, while those coming as family members may get information from settled family members on jobs. The situation is generally most critical for those who come as refugees with no earlier knowledge of the labor market and being without relatives and friends meeting and guiding them in the new country.

\subsection{Migrants}

Several studies using different methods show that foreign-born may suffer discrimination in the labor market. They are for example less often called for interviews when applying for a job, and when interviewed for a job they are less often hired. Discrimination in the first phase of the hiring process has been revealed in many different countries. ${ }^{20}$ by sending job applications to a number of employers with the same merits regarding CV etc for applicants

\footnotetext{
${ }^{19}$ See for example several studies by Barry Chiswick but also a critique of Georges Borjas who stress that cohorts differ and that cross sectional analysis may therefore be misleading. See for example Chiswick (1978) and Borjas (1991). Selection may also be due to selective return migration - those not succeeding return or move to another country.

${ }^{20}$ On ethnic discrimination tested by correspondence testing see e.g. Carlsson and Rooth (2007) on Sweden, Drydalis and Vlassis (2010) on Greece, and Riach and Rich (1991) on Australia.
} 
with names common among natives and foreign-born, respectively. The name and the applications are combined by lottery.

There are several forms of discrimination. One important form is information-based discrimination. ${ }^{21}$ The basis for that theory is that the quality of migrant labor is not easy to evaluate. In its simplest form, the employer is just misinformed and discriminates because of that. ${ }^{22}$ An employer may believe that foreign-born applicants are less qualified than the native born, even if they are equally productive in practice, and discriminates based on this misinformation. The most well-known form of information-based discrimination is statistical discrimination, which builds on the idea that the employer does not have information on individual abilities of the applicants but has easily available and inexpensive information on average ability or variance in ability of workers belonging to various groups. If those who are foreign-born on average have lower productivity than natives (for example due to lack of knowledge of the language in the country of destination), employers may not hire foreignborn workers with a high (unknown) ability, or hire them only with lower wages. The average values for different groups are used when recruiting. Also if it is known that foreign-born and natives have the same productivity, but the variance in the estimation of the individual's productivity is higher for foreign-born than for natives, a risk-averse employer avoids the foreign-born. Those with the same school tie as the employer are easier to evaluate than those who are foreign-born or with another ethnic background than the employer and the natives are therefore hired. ${ }^{23}$ It underlines that the ethnic backgrounds of the employers and those who make the hiring decisions are important.

Standardization of educational systems such as through the Bologna process for higher education in Europe may make it easier to compare education acquired in different European countries. ${ }^{24}$ In the same way the founding of common labor markets such as the Common Nordic Labor Market and the Common European Labor Market may both result in education

\footnotetext{
${ }^{21}$ See Phelps (1972b). There are other types of discrimination theories as those based on preferences of the Becker type and monopsonistic discrimination. See Becker (1957) and Manning (2003), respectively. See also Arrow (1972a, 1972b and 1973) for important contributions to the development of the economic theory of discrimination. We do not deal with those forms of discrimination here as they are not in the same way closely related to labor market transparency. See Lundahl and Wadensjö (1984) for a survey and comparison of different discrimination theories.

${ }^{22}$ See McCall (1972 and 1973) for analyses of this case.

${ }^{23}$ There may of course be some occupations there the employer is willing to take a risk to increase the possibility to get a star, for example in sports and arts. The high variance in expected ability increases the chances to get a star recruited and by that the possibility to get a very high reward.

${ }^{24}$ The Bologna process is agreements between European countries designed to ensure comparability in the standards and quality of higher education qualifications. The Bologna process has at present 47 participating countries, i.e. almost all countries in Europe.
} 
credentials being formally accepted (certified) in other countries than where they are acquired (for example for medical doctors, nurses, electricians) and in employers being more keen to employ those coming from other countries. It should also be noted that there are systems of ranking of universities world-wide which may give some guidance regarding the quality of education in different universities.

\subsection{Comparable and transparent information on migration and for migrants}

Comparable information on labor market conditions in different countries may be found in a variety of sources. The producers are mainly international organizations that have governments as members, but NGOs also take part in information collection and dissemination. It should be stressed that there are problems comparing labor market statistics from different countries as definitions, ways of collecting statistics and quality vary.

ILO is one source which covers most of the world (Taiwan is one of only a few exceptions due to that the country is not a member of the UN). It provides information regularly on wages and employment and also publishes studies of specific countries or comparing countries. See www.ilo.org. Two of sections on the website are on "statistics and databases" and "labor standards".

The OECD also publishes detailed information for the member countries and also a yearly book on international migration. The yearbooks contain a wealth of statistics on international migration as well as chapters covering the general development and sections on specific topics. For example, the 2011 yearbook, OECD (2011), contains sections on migrant entrepreneurship and international migration to Israel and the 2012 yearbook, OECD (2012), has sections on migration policy development and the changing role of Asia in international migration.

Eurostat collects and publishes labor statistics for the 27 member countries of the European Union. See www.ec.europa.eu/eurostat. One section contains statistics on population and social conditions and includes information from the labor force surveys in the member countries. The European Union publishes statistical information not only regarding the member states but also some information regarding the labor markets of the candidate states. There is also information on other regional levels as for example for the five Nordic countries. See www.norden.org. A Nordic Statistical Yearbook is published and much comparable statistics is to be found on the website. 
There is also some regularly published information on how migrants are treated in various countries. One example is the Migrant Integration Policy Index which compares the integration policy in the European Union countries in various fields: labor market mobility, family reunion, education, political participation, long-term residence, access to nationality and anti-discrimination. ${ }^{25}$

Another example is International Organization for Migration (IOM) which published a large report on how to improve information access for both migrants and employers (International Organization for Migration, 2013a) and another on the recognition of qualifications and competences of migrants (International Organization for Migration, 2013b). The first report contains separate chapters on good practices and recommendations from five selected EU member states (Germany, Italy, Poland, Sweden and the United Kingdom) and two other countries (Canada and the United States). The second report contains separate chapters on good practices and recommendations from six selected EU member states (Denmark, Germany, Italy, the Netherlands, Sweden and the United Kingdom) and two other countries (Australia and Canada).

As earlier underlined, the most important information for the prospective migrants is most likely information from people in their networks who have already migrated.

We have here only dealt with information regarding migrants on the formal labor market. There are in most countries also irregular migrants being employed on the informal labor market. This group is large in some countries. The authorities lack reliable information on the size and composition of this group and also the employees and the employers may have limited information with large differences in wages and working conditions.

There may also be lack of information on the immigration policy and especially the future immigration policy. Changes in the immigration policy may have large consequences both for those who have already migrated and for those who intend to migrate later on. One example on that is the proposed change of the US immigration policy, which may lead to a better situation for many who have already immigrated but to more hinder for some of those who want to migrate to the US in the future.

\footnotetext{
${ }^{25}$ See Huddleston et al. (2011)
} 


\section{Political decisions and labor market transparency}

The political authorities may improve the transparency of the labor market, for example through information, laws and design of different policy programs.

Public employment exchanges have been introduced in many countries with the intention to improve information on job vacancies and thereby to improve the worker-job matching in the labor market. But even in countries with well-functioning and well-equipped employment exchanges, they do not cover the total labor market despite some countries are prohibiting private employment exchanges. And they do not have full information on their customers (employers, job seekers).

There are several other ways of finding job vacancies, as via newspaper advertisements, internet and personal networks and by directly asking for jobs at different employers. How jobs are found usually differs between different segments of the labor market. In some segments, networks are most important for finding a job, while in other segments formal application procedures for announced jobs are most important. It is more complicated for job applicants to get an overview of alternatives in some segments of the labor market, especially those with many employers who each have only a few employees.

The political authorities may decrease the differences in the reward structure between the jobs by legislation and by making it easier to compare different job offers. Legislation regarding working hours, overtime, vacation length and other work condition may make the differences in these respects to disappear or at least be smaller in those dimensions between employers so that those comparing jobs may concentrate on fewer characteristics of the employment contract.

In the same way, legislation regarding public pensions, sickness benefits and other forms of income transfers but also health care may make differences between job offers disappear or become smaller, facilitating the comparison of remuneration in different jobs.

Agreements between unions and employer associations regarding work conditions and occupational insurance may make jobs more equal and facilitate the comparison of different jobs. Rules being the same in different jobs facilitate comparisons and transferability of occupational insurances facilitates mobility. Important is here also that the authorities working with work safety enforce high minimum standards. 
Another important part of the public policy related to the transparency of the labor market is the labor market policy. ${ }^{26}$ An integral part of that policy is in most countries the public employment service, which gathers information on vacant jobs and job applicants and tries to match jobs and applicants. Another part of that policy is to facilitate occupational or geographical mobility by training and mobility grants. A third part of the labor market policy is to subsidize jobs in the private or public sector to increase the labor demand for those out of jobs. It should here be noted that there are connections between the labor and housing markets. Regional mobility may be hindered by a lack of transparency in the housing market.

\section{Conclusions}

There are serious problems with lacking transparency in the labor market. The labor market is a complicated market for several reasons. You have to be at the work place to deliver your labor. The transparency of work place conditions may be lacking for those looking for a job. The workers differ from each other in several respects. The transparency of the qualifications of the job applicants may be lacking for the employers. And the jobs offered vary and the jobs often change as a result of who is hired. Important in this connection is that all individuals are not interested in the same information. Those leaving secondary school are for example interested in other information than those who have just completed a university education or are established in an occupation in the labor market. The dentists are for example not generally interested in the labor market situation for engineers and vice versa.

It is not easy to get a good picture of the different aspects for those on both sides of the labor market, neither for those searching for a job nor for employers wanting to hire workers. The information is asymmetric. It is even more difficult for the foreign-born and for employers who receive job applications from those with credentials from another country. The transparency of the labor market is to a high extent incomplete. The public authorities also lack vital information on the actual functioning and the results of the labor market. Agreements and knowledge of the existence of agreements are also important for transparency in the labor market.

The politicians, the public authorities, and the social partners may by laws, public policy programs and collective agreements make the conditions more similar irrespective of which

\footnotetext{
${ }^{26}$ See Schmid et al. (1996) for a number of surveys on labor market policy.
} 
the employer is and by that increase the transparency in the labor market and promote mobility.

\section{References}

Akerlof, George A. (1982), “Labor Contracts as Partial Gift Exchange”, Quarterly Journal of Economics, Vol. 97(4), pp. 543-569.

Arrow, Kenneth (1962), “The Economic Implications of Learning by Doing”, Review of Economic Studies, Vol. 29(3), pp. 155-173.

Arrow, Kenneth J. (1972a), “Models of Job Discrimination”, in Anthony Pascal (ed.), Racial Discrimination in Economic Life. Lexington, Mass.: D.C. Heath.

Arrow, Kenneth J. (1972b), “Some Mathematical Models of Race in the Labor Market”, in Anthony Pascal (ed.), Racial Discrimination in Economic Life. Lexington, Mass.: D.C. Heath. Arrow, Kenneth J. (1973), "The Theory of Discrimination", in Ashenfelter, Orley and Rees, Albert (eds.), Discrimination in Labor Markets. Princeton: Princeton University Press.

Autor, David H. (2001), “Wiring the Labor Market”, Journal of Economic Perspectives, Vol. 15(1), pp. 35-40.

Autor, David H. (2013), “The ‘task’ approach to labor markets: An overview”; NBER Working Paper 18711.

Becker, Gary S. (1957), The Economics of Discrimination, Chicago: The University of Chicago Press.

Becker, Gary (1964), Human Capital. A theoretical and empirical analysis, with special reference to education, New York: Columbia University Press.

Borjas, Georges (1991), “Self-Selection and the Earnings of Immigrants”, American Economic Review, Vol. 77(4), pp. 531-553.

Carlsson, Magnus and Dan-Olof Rooth (2007), "Evidence of ethnic discrimination in the Swedish labor market using experimental data”, Labour Economics, Vol. 14(4), pp. 716-729.

Chiswick, Barry (1978), “The Effect of Americanization on the Earnings of Foreign-born Men”, Journal of Political Economy, Vol. 86(5), pp. 897-921. 
Dow, J. C. R. and Louis Dicks-Mireaux (1958), “The Excess Demand for Labour: A Study of Conditions in Great Britain, 1946-1956”, Oxford Economic Papers, Vol. 10(1), pp. 1-33.

Drydakis, Nick and Minas Vlassis (2010), “Ethnic discrimination in the Greek Labour Market: Occupational Access, Insurance Coverage and Wage Offers”, The Manchester School, Vol 78(3), pp. 201-218.

Ebbinghaus, Bernhard (ed.) (2011), Varieties of Pension Governance: Pension Privatization in Europe, Oxford University Press, Oxford.

Granovetter, Mark (1973), “The Strength of Weak Ties”, American Journal of Sociology, Vol. 78(6), pp. 1360-1380.

Granovetter, Mark (1983), “The Strength of Weak Ties: A Network Theory Revisited”, Sociological Theory, Vol. 1, pp. 201-233.

Granqvist, Lena (1997), ”Sidoförmåner - skillnader mellan män och kvinnor”, in SOU 1997:136, Kvinnors och mäns löner - varför så olika?

Granqvist, Lena (1998), A Study of Fringe Benefits. Analysis Based on Finnish Micro Data; Dissertation from the Swedish Institute for Social Research, Stockholm University, no 33. Houseman, Susan N., Arne L. Kalleberg and George A. Erickcek (2003), “The Role of Temporary Agency Employment in Tight Labor Market”, Industrial \& Labor Relations Review, Vol. 57(1), pp. 105-127.

Huddleston, Thomas, Jan Niessen with Eadaoin Ni Chaoimh and Emilie White (2011), Migrant Integration Policy Index III, Brussels: British Council and Migration Policy Group. International Organization for Migration (2013a), Improving Access to Labour Market Information for Migrants and Employers, Brussels: IOM.

International Organization for Migration (2013b), Recognition of Qualifications and Competences of Migrants, Brussels: IOM.

Jovanovic, Boyan (1979), “Job Matching and the Theory of Turnover”, Journal of Political Economy, Vol. 87(5), pp. 972-990.

Katz, Eliakim and Oded Stark (1987), “International Migration under Asymmetric Information”, Economic Journal, Vol. 97(387), pp. 718-726.

La lettre de l’Observatoire des Retraites (2010), “Informing the European Working Population of their Pension Benefits”, Paris: Observatoire des Retraites. 
Lazear, Edward (1999), “Personnel Economics: Past Lessons and Future Directions”, Journal of Labor Economics, Vol. 17(2), pp. 199-236.

Lazear, Edward P. and Kathryn L. Shaw (2007), “Personnel Economics: The Economist's View of Human Resources”, Journal of Economic Perspectives, Vol 21(2), pp. 91-114.

Lundahl, Mats and Eskil Wadensjö (1984), Unequal Treatment. A Study in the Neoclassical Theory of Discrimination, London: Croom Helm.

Manning, Alan (2003), Monopsony in Motion. Imperfect competition in labor markets, Princeton, Princeton University Press.

Manning, Alan (2011), "Imperfect competition in the labor market”, in Orley Ashenfelter and David Card (eds.), Handbook of Labor Economics, Vol. 4b. Amsterdam: Elsevier.

McCall, John J. (1972), “The Simple Mathematics of Information, Job Search, and Prejudice” in Anthony Pascal (ed.), Racial Discrimination in Economic Life, Lexington, Mass.: D.C. Heath.

McCall, John J. (1973), Income Mobility, Racial Discrimination and Economic Growth, Lexington Mass.: Lexington Books.

Montgomery, James D. (1982), “Social Networks and Labor-Market Outcomes: Toward an Economic Analysis”, American Economic Review, Vol. 81(5), pp. 1408-1418.

Mortensen, Dale T. (1986), “Job Search and Labor Market Analysis” in Orley Ashenfelter and Richard Layard (eds.), Handbook of Labor Economics, Volume 2, Amsterdam: North Holland.

Mortensen, Dale T. and Christopher Pissarides (1999), "New Developments in Models of Search in the Labor Market” in Orley Ashenfelter and Richard Layard (eds.), Handbook of Labor Economics, Volume 3B, Amsterdam: Elsevier.

OECD (2011), International Migration Outlook. SOPEMI 2011, Paris: OECD publishing. OECD (2012), International Migration Outlook 2012, Paris: OECD publishing. Olli Segendorf, Åsa (2005), Job Search Strategies and Wage Effects for Immigrants, Dissertation from the Swedish Institute for Social Research, Stockholm University, No. 65. Oyer, Paul and Scott Schaefer (2011), "Personnel Economics: Hiring and Incentives”, in Orley Ashenfelter and David Card (eds.), Handbook of Labor Economics, Vol. 4b. Amsterdam: Elsevier. 
Phelps, Edmund S. (ed.) (1970), Microeconomic Foundations of Employment and Inflation Theory, New York: W.W. Norton.

Phelps, Edmund S. (1972a), Inflation Policy and Unemployment, New York: W.W. Norton Phelps, Edmund S. (1972b), “The Statistical Theory of Racism and Sexism”, American Economic Review, Vol 62(4), pp. 659-661.

Rees, Albert (1966), “Networks in the Labor Markets”, American Economic Review, Vol. 56(1/2), pp. 559-566.

Riach, Peter A. and Judith Rich (1991), “Testing for racial discrimination in the labour market”, Cambridge Journal of Economics, Vol. 15(3), pp. 239-256.

Schmid, Günther, Jacqueline O’Reilly and Klaus Schömann (eds.) (1996), International Handbook of Labour Market Policy and Evaluation, Cheltenham, UK and Brookfield, US: Edward Elgar.

Shapiro, Carl and Joseph E. Stiglitz (1984), “Equilibrium Unemployment as a Worker Discipline Device”, American Economic Review, Vol. 74(3), pp. 433-444.

Sjögren Lindquist, Gabriella and Eskil Wadensjö (2006), National Social Insurance - not the whole picture. Supplementary compensation in case of loss of income, ESS Report 2006:5. Smith, Adam (1776; 1981), An Inquiry into the Nature and Causes of the Wealth of Nations, Indianapolis, In: Liberty Classics.

Spence, Michael (1974), Market Signaling: Informational Transfer in Hiring and Related Screening Processes, Cambridge Mass.: Harvard University Press.

Stigler, George J. (1962), “Information in the Labor Market”, Journal of Political Economy, Vol. 70(5, part 2), pp. 94-105. 